\section{Reviewers of the Year: improving the quality of the journal and the field}

\author{
Ruth E Malone
}

As we try to do each year in an early issue, we honour peer reviewers who go above and beyond in their contributions to the journal and the field by naming them as Reviewers of the Year. The glory is fleeting and the reward, an electronic subscription to Tobacco Control, lasts only 1 year, but the benefits of their work are incalculable and lasting. Nominated by one or more of our senior editorial team, each of the individuals named below has taken to heart the responsibility of a peer reviewer to be both critical and constructive, helping authors move their work to the next level.

Peer reviewing is a skill, takes time to do well, and not everyone takes it seriously. Short of repeated refusals to review at all, there is nothing more disconcerting for an editor than to receive a one-sentence or two-sentence review that says something equivalent to 'good paper' or 'bad paper'. Such reviews are meaningless to us, unhelpful to authors, and an abdication of scholars' and scientists' commitment to their field. Further, they reflect poorly on one's scientific engagement with the field. Such remiss reviewers have often themselves benefited previously from the contributions of others to reviewing their own work, so it is always deeply disappointing to us as editors to find they have not reciprocated.

However, in fairness, not everyone has benefited from good mentoring in terms of what their role as a peer reviewer should and could be. For those who are unsure or inexperienced, reviewing the Ethical Guidelines for Peer Review from the Committee on Publication Ethics, available here: (https://publicationethics.org/files/Ethical_Guidelines_ For_Peer_Reviewers_2.pdf) can be a good start to developing this aspect of your professional life. It will be time well spent, because expertise in peer review helps build one's reputation in the field, increases critical skills, and counts toward academic advancement in many contexts.

A good review for Tobacco Control is not simply about finding weaknesses in scientific methods, copyediting, or

Correspondence to Professor Ruth E Malone, Social and Behavioral Sciences, University of California, San Francisco, San Francisco, California, USA; ruth.malone@ucsf.edu making comments about paper structure, although these are important. A good review also considers the larger context within which the policy-relevant work we publish will appear, and the implications thereof. We hope that all our readers will salute and eventually join these individuals, honoured as our Reviewers of the Year for 2019, and listed in alphabetical order.

Micah Berman, an Associate Professor at University of Ohio, has provided the unique and important perspective of a public health attorney and legal scholar. For one paper, the handling editor noted his expertise in astutely clarifying for authors how important it was to properly frame their research, in order to ensure that readers understood distinctions between the types of public-facing statements published by tobacco companies.

Timothy Dewhirst, a longstanding member of the editorial board and one of our most prolific reviewers, is Professor in the Department of Marketing and Consumer Studies at University of Guelph. He also did a wonderful job, according to the nominating editor, with reframing the context to make a paper about one brand of tobacco products more relevant to an international audience. 'This paper will have greater impact because of his critical and helpful comments', the editor noted.

Jacqui Drope, Managing Director, Global Cancer Prevention at American Cancer Society, is a volunteer in an illustrious group who commit their time to working with low-income country authors. At Tobacco Control, we sometimes receive manuscripts that have worthy content, but need a lot of help even to become competitive to go out for peer review. Her blend of experience in capacity building, research, and communications has made her a wonderful mentor to several authors just learning the ropes. She understands how influential having even a single publication in an international journal can be in some small countries where little in-country research has ever been done.

Jeffrey Drope, Scientific Vice President, Economic and Health Policy Research at American Cancer Society, was also nominated for his generosity in helping authors from low-income countries whose first language is not English and who sometimes have fewer research training resources available to them than wealthy country authors do. Dr Drope makes time to help (and sometimes collaborate with) authors of those papers, and he does so with sensitivity and respect.

Thomas Eissenberg, a Professor in Health Psychology at Virginia Commonwealth University, is another frequent reviewer and has more than once come through with very fast and thorough reviews of papers the editors perceive to be particularly timely for the field. His reviews, according to editors, are brilliant examples of the best in peer reviewing, with wonderful and innovative suggestions for how to fix otherwise-fatal flaws, delivered with tact and encouragement.

April Roeseler, Chief of the California Tobacco Control Programme, is among our best reviewers with expertise in applying the findings published in the journal to advance on-the-ground tobacco control policies and programme. The journal benefits greatly from the federal, state and local tobacco control programme leaders who participate in peer review, as they offer a critical perspective on the value of research for policy implementation and enforcement. She was nominated for a review that provided authors with excellent guidance about reframing the narrative and approach to maximise the potential impact of their work and to highlight a model that would encourage future cross-collaborations.

Rebecca Williams, a researcher at the University of North Carolina Lineberger Comprehensive Cancer Center and Chief Technology Officer of the Cancer Prevention and Control Research Network, is honoured by the senior editorial team for her exquisite skills in providing 'extensive but useful' comments both for details and for positioning the work in larger context and pulling out policy implications. Her expertise in the study of online tobacco marketing, a particularly challenging global policy issue, is invaluable.

Our sincere thanks to all those who contributed their valuable time to reviewing, and warmest congratulations to those honoured this year!

\section{Twitter Ruth E Malone @MaloneRuth}

The authors have not declared a specific grant for this research from any funding agency in the public, commercial or not-for-profit sectors. 


\section{Editorial}

Competing interests https://tobaccocontrol.bmj. com/pages/wp-content/uploads/sites/49/2019/10/DOIStatement-Ruth-Malone.pdf

Patient consent for publication Not required.

Provenance and peer review Not commissioned; internally peer reviewed. (c) Author(s) (or their employer(s)) 2020. No commercial re-use. See rights and permissions. Published by BMJ.

\section{(D) Check for updates}

To cite Malone RE. Tob Control 2020;29:1-2.
Tob Control 2020;29:1-2.

doi:10.1136/tobaccocontrol-2019-055536

ORCID iD

Ruth E Malone http://orcid.org/0000-0002-3324-2183 